\title{
Development and Expert Review of iZakat Kedah Mobile Application
}

\author{
https://doi.org/10.3991/ijim.v15i20.23715 \\ Azizah Che Omar ${ }^{1(凶)}$, Nurulnadwan Aziz², Mohd Adib Abd Muin³, Subashini A/P \\ Annamalai ${ }^{1}$, Muhamad Amar Mahmad ${ }^{3}$ \\ ${ }^{1}$ Universiti Utara Malaysia Sintok, Kedah, Malaysia \\ ${ }^{2}$ Universiti Teknologi MARA, Terengganu, Malaysia \\ ${ }^{3}$ Universiti Utara Malaysia, Kedah, Malaysia \\ co.azizah@uum. edu.my
}

\begin{abstract}
Zakat is a mandatory practice in Islam. The purpose of zakat is to help the society, share the endless boons of Allah and assists the unfortunate people to have a better quality of life. The concept of Zakat is to purify the Muslim wealth and soul. Calculation of Zakat is based on the total savings of a Muslim during one lunar (Islamic) year. Even though, paying Zakat is compulsory for all Muslims however, the knowledge of zakat and the calculation of zakat is still insufficiently explored by the Muslims themselves. Based on the initial study that has been carried out, most of the Muslims still blur and confuse in understanding the concept of zakat and the calculation of zakat. Therefore, iZakat Kedah mobile application has been developed to provides understanding of the zakat income and the calculation of zakat. Thus, this paper focuses on the development of iZakat Kedah mobile application which has been carried out through comparative analysis study and the evaluation of the proposed application through expert review method. Findings of the study indicates that most of the experts agreed that the iZakat Kedah mobile application provides useful knowledge in terms of zakat information and zakat calculation to the public particulary for Muslims.
\end{abstract}

Keywords - mobile interaction, interaction design, comparative analysis, mobile application, zakat, expert review, user experience

\section{$1 \quad$ Introduction}

Zakat is one of the five fundamental pillars of Islam. Allah (s.w.t.) and it is categorized under obligatory charity $[4,1]$. The zakat system if managed efficiently will definitely have a positive impact on the socio-economic positions of the poor and needy among the Ummah [5,7]. Zakat has a number of objectives. The first is the purification of one's wealth. Payment of zakat is a divinely ordained method to cleanse one's heart and soul from greed and obsession for material wealth $[2,4]$. This enhances one's love for Allah (s.w.t.) making one an obedient servant to Him. Even though, paying Zakat is compulsory for all Muslims however, the understanding regarding the concept of zakat 
and the zakat calculation still insufficiently explored by the Muslims themselves $[3,6]$. Therefore, iZakat Kedah mobile application has been proposed in this study to provides better understanding to the Muslims particularly in terms of the concept of zakat and the calculation of zakat [8].

Based on previous research, most of the existing applications of zakat is too simple and less friendly to the users. It was found that, some of the application excluded the zakat calculation. Therefore, this study proposes the iZakat Kedah mobile application called iZakat Kedah that provides complete information of zakat income and the features of zakat calculation. Besides, iZakat Kedah provides interactive and interesting interaction design which enable the users to get the information automatically compared to the conventional method where the Muslims need to attend the seminars, talks, or physically go to the zakat district office to get the information of zakat. To achieve the main aim of the study, specifics objectives were formulated as stated in the next point:

i. To develop the iZakat Kedah mobile application through comparative analysis method.

ii. To evaluate iZakat Kedah mobile application through expert review method.

\section{Comparative analysis of existing Zakat applications}

To identify the research gap and to extract the components and elements of existing zakat applications a comparative analysis method has been carried out. They are described in the next subsection.

\section{1 eZakat}

This application is an eZakat application from Lembaga Zakat Selangor. eZakat allows user to check previous zakat payment and access information regarding zakat. This application contains five menus, firstly home menu that consists the news of Lembaga Zakat Selangor, information or knowledge of zakat, section of information on zakat payment and form for users to make the zakat payments through online. Next, calculator for user to calculate their zakat income, business, gold and the related income. This application also provides eZakat menu that allows user to login their account by inserting username and password. Besides, branch menu which list all office branch in Selangor make it easier for user to find the nearest zakat branch and get direction to reach there via Maps as well as complete information including telephone number and fax number. This application has menu that allows user to make reports for individuals categorized as asnaf.

\subsection{Kalkulator zakat terbaik}

This application contains mp3, calculator, and fiqih zakat. Fiqih zakat is one of the disciplines in Islam. The mp3 provides information of zakat (i.e. the important of zakat). The calculator function to calculate the zakat income, trade, gold, and savings. Fiqih zakat provides information for user to improve the understanding of zakat. It contains 
multimedia elements (i.e. sound, text, and image). The application also provides a smooth navigation system.

\subsection{Kalkulator zakat pendapatan 2013}

This application only provides calculator. User need to insert the number of salary and click calculate zakat button. Then, the amount of zakat that need to pay by the user will appear. Only two multimedia elements contain in this application which are image and text. There are no sound and video provides in this application. It is simple and outdated after a year. Besides, this application also not supported by the latest version of android.

\section{$2.4 \quad$ Kalkulator Zakat}

Kalkulator Zakat utilizes Microsoft Excel and there is no interface or any multimedia elements provides in this application. It is online application and unsuitable to be run on android.

\subsection{MyZakat Kedah}

MyZakat Kedah is the zakat application that provides specifically for Kedah state, Malaysia. It contains seven menus. There are zakat information, report of zakat collection, distribution of zakat, zakat payment search, search for zakat recipients, ICT complaint system, and menu for user to $\log$ in the system. To use the system users need to sign up the system. If not, they only enable to view the zakat information.

\subsection{Matrix analysis table}

To provides a more comprehensive comparative analysis this study also carried out the matrix analysis table as tabulated in Table 1.

Table 1. The matrix analysis of the existing zakat applications

\begin{tabular}{|l|c|c|c|c|c|c|c|c|}
\hline \multicolumn{1}{|c|}{ Application } & Alphabet & Text & Image & Video & Audio & Location & Calculation & Animation \\
\hline eZakat & $/$ & $/$ & $/$ & $\mathrm{x}$ & $\mathrm{x}$ & $/$ & $\mathrm{x}$ & $\mathrm{x}$ \\
\hline $\begin{array}{l}\text { Kalkulator Zakat } \\
\text { Terbaik }\end{array}$ & $/$ & $/$ & $/$ & $\mathrm{x}$ & $/$ & $\mathrm{x}$ & $/$ & $\mathrm{x}$ \\
\hline $\begin{array}{l}\text { Kalkulator Zakat } \\
\text { Pendapatan 2013 }\end{array}$ & $/$ & $/$ & $/$ & $\mathrm{x}$ & $\mathrm{x}$ & $\mathrm{x}$ & $/$ & $\mathrm{x}$ \\
\hline Kalkulator Zakat & $/$ & $\mathrm{x}$ & $\mathrm{x}$ & $\mathrm{x}$ & $\mathrm{x}$ & $\mathrm{x}$ & $/$ & $\mathrm{x}$ \\
\hline MyZakat Kedah & $/$ & $/$ & $/$ & $\mathrm{x}$ & $\mathrm{x}$ & $\mathrm{x}$ & $\mathrm{x}$ & $\mathrm{x}$ \\
\hline iZakat Kedah & $/$ & $/$ & $/$ & $/$ & $/$ & $/$ & $/$ & $/$ \\
\hline
\end{tabular}

Based on the performed matrix analysis (Table 1) this study a proposes a new matrix analysis to fulfil the drawbacks found in the existing applications. iZakat Kedah tabulated the new matrix analysis proposes by this study. 


\section{$3 \quad$ Methodology}

To achieve the main of the study a series of research activities has been conducted as illustrated in Figure 1.

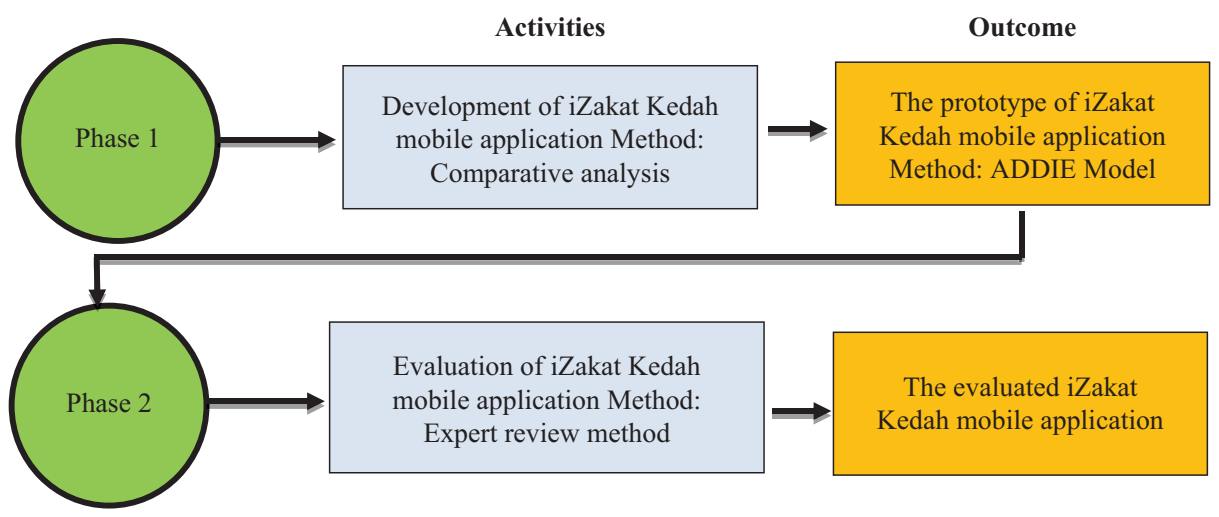

Fig. 1. Research activities of the study

This study consists of two phases. The first phase begins with the development of iZakat Kedah mobile application. A comprehensive comparative analysis has been conducted to extract the main components and elements required in the proposed prototype. ADDIE Model has been utilized to develop the iZakat Kedah mobile application which discussed details in the next section. Upon complete the development, iZakat Kedah mobile application has to be evaluated. Expert review method has been carried out to evaluate the proposed application. This study selects three academicians who experts in mobile application and two content experts from higher learning institution to evaluate the proposed application. In addition, officer from Office of Zakat Kedah also involves as the content expert.

Face-to-face consultation has been carried out with the experts during the evaluation process. Prior to start the evaluation, this study briefs the experts regarding the purpose and objective of iZakat Kedah mobile application. Then, the iZakat Kedah mobile application was played to them. The experts started to observe and use the proposed application. Having experience in using the iZakat Kedah mobile application then, a series of interview were conducted. The interview questions consist of three main section. There are (i) user interface, (ii) ease of use, and (iii) user usefulness. Experts response and verbal comments has been jotted down and discussed in this study.

\section{The development of izakat kedah mobile application}

This study adopts the ADDIE model to develop the iZakat Kedah mobile application. It consists of five main phases which are (i) analysis (ii) design (iii) development (iv) implementation, and (v) evaluation. The details of the development process were described in Table 2. 
Table 2. ADDIE model of iZakat Kedah mobile application

\begin{tabular}{|c|c|}
\hline Phase & Description \\
\hline Analysis & $\begin{array}{l}\text { - Identify the target users } \\
\text { - There are persons who earned income from service reward } \\
\text { - This include employer, individual, company, and institution } \\
\text { - Analysed the user needs } \\
\text { - Determine the applicable features } \\
\text { - This include the concept, font style, color and navigation button }\end{array}$ \\
\hline Design & $\begin{array}{l}\text { - Design the storyboard } \\
\text { - Design the interface and navigation button using the Abode Photoshop and Adobe } \\
\text { Illustrator } \\
\text { - Organize the navigation specification }\end{array}$ \\
\hline Development & $\begin{array}{l}\text { - Develop the application of iZakat Kedah mobile application by utilizing Android } \\
\text { Studio software }\end{array}$ \\
\hline Implementation & - Check the functionality of iZakat Kedah mobile application \\
\hline Evaluation & - Involves the target users to evaluate the iZakat Kedah mobile application \\
\hline
\end{tabular}

\subsection{User interface of Izakat Kedah mobile applications}

The interfaces of iZakat Kedah mobile application are as depicted in Figure 2 to Figure 9. The application starts with the flash screen of iZakat Kedah (Figure 2). The user then navigated to main page of application which consists of five main menus. There are (i) Kalkulator Zakat, (ii) Informasi Zakat, (iii) Ceramah Zakat, (iv) Berita Zakat and (v) Lokasi Zakat. Two methods of calculation were provided which are method A and method B. On page Ceramah Zakat users can learn and understand the concept of zakat through seminars and talks. Meanwhile, on page Berita Zakat users obtain new info regarding zakat activities in Kedah State, Malaysia. The last but not least is page Lokasi Zakat where the users able to access the direction of Zakat Office Branch in Malaysia. 

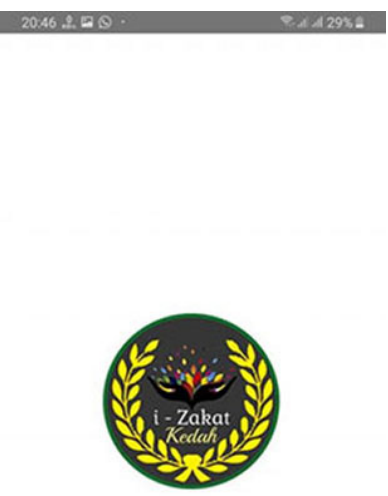

III

Fig. 2. Flash

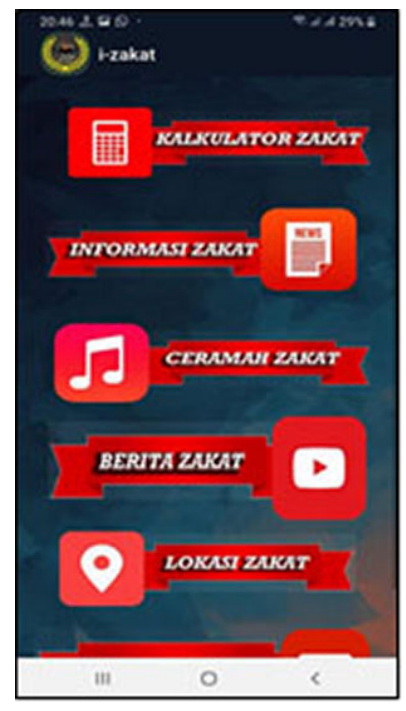

Fig. 3. Main menu 


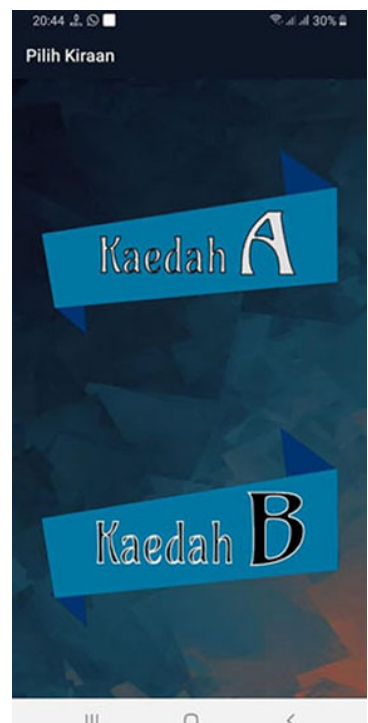

Fig. 4. Kalkulator

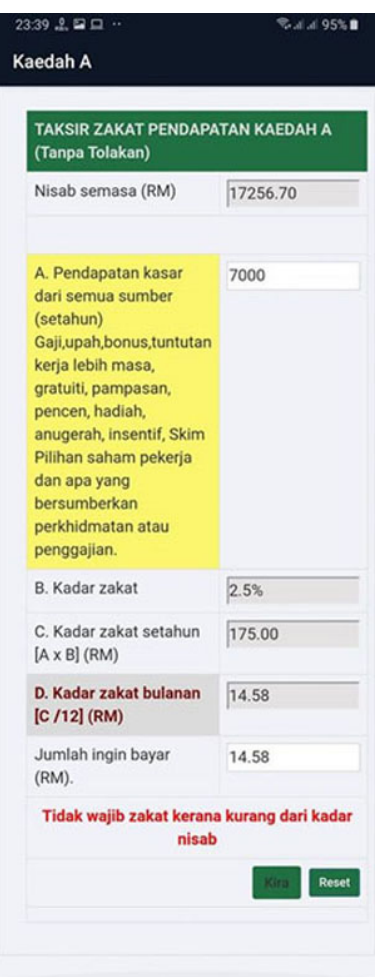

Fig. 5. Kalkulator zakat; Kaedah A 


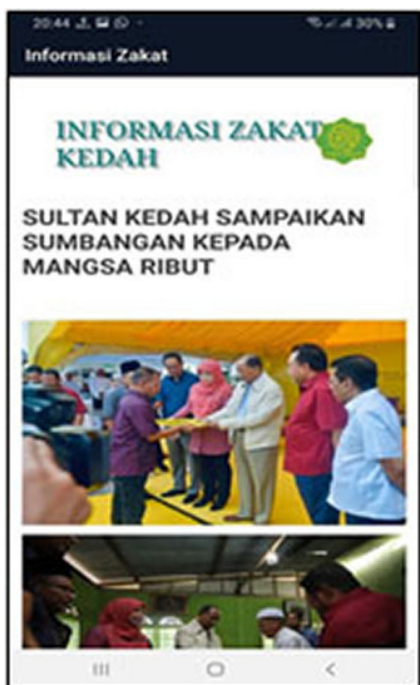

Fig. 6. Informasi zakat

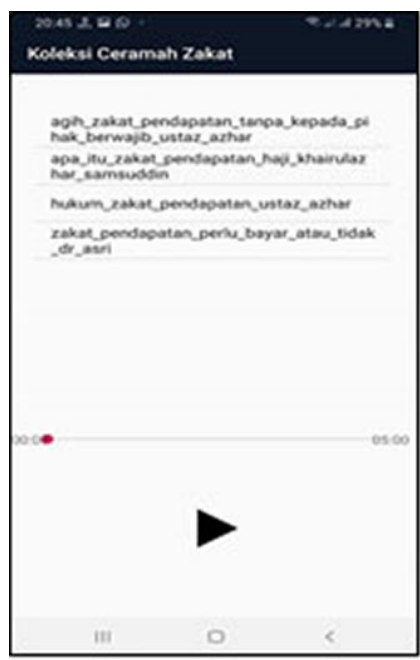

Fig. 7. Ceramah zakat 


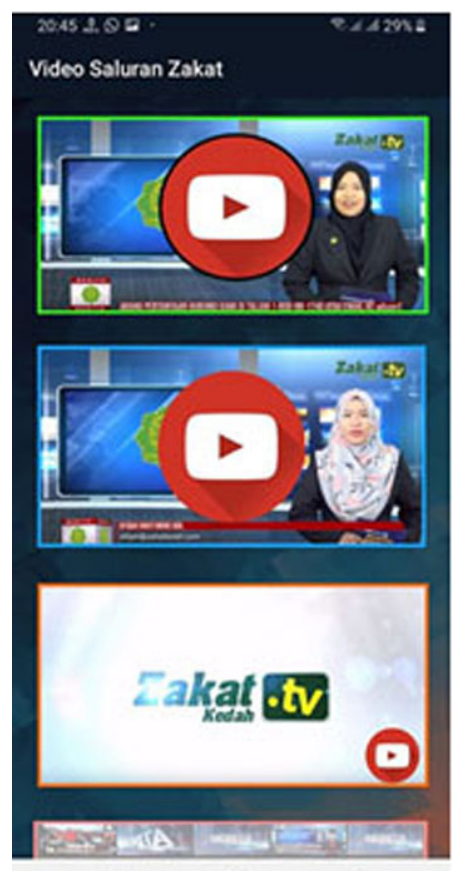

III

o

Fig. 8. Berita zakat

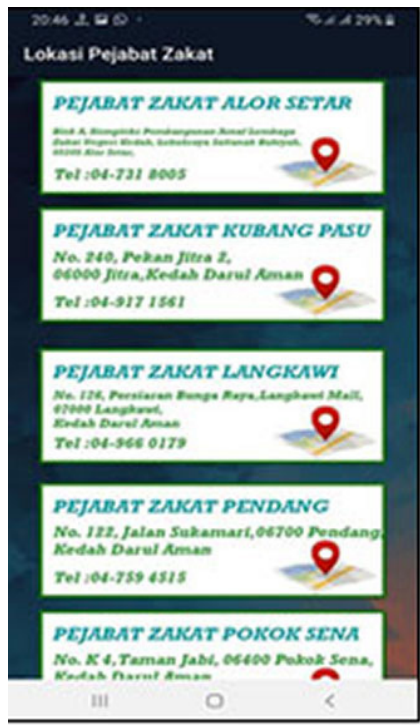

Fig. 9. Lokasi zakat 


\section{$5 \quad$ Finding and discussion}

As discussed in the methodology section, there are six expert's majority from higher learning institutions involves in the evaluation phase. There are selected based on their expertise. Experts on Mobile Application are from School of Multimedia and Communication. Then, content experts particularly on zakat knowledge are from Islamic Studies School including an officer from Zakat Kedah Office. The proposed mobile application was evaluated in terms of (i) user interface, (ii) ease of use, (iii) and usefulness. A set of closed-ended interview questions were asked during the evaluation. There are discussed in the next subsection.

\subsection{User interface}

Table 3 listed the questions related to user interface of iZakat Kedah mobile application.

Table 3. Questions on user interface

\begin{tabular}{|l|l|}
\hline \multicolumn{1}{|c|}{ No. } & \multicolumn{1}{c|}{ Questions } \\
\hline Q1 & Does the arrangement of the button is suitable? \\
\hline Q2 & Does the use of font is appropriate? \\
\hline Q3 & Does the use of colour is attractive? \\
\hline Q4 & Does the applied graphics and image are appropriate? \\
\hline
\end{tabular}

Regarding Q1 all experts agreed with the arrangement of buttons, however they comment on the size of the buttons. Then, Q2 related to the appropriateness of font were asked. It is resulted that all of the experts agreed with the use of font in iZakat Kedah mobile application. Going through the third questions (Q3) regarding the attractiveness of color, majority of the experts agreed with the use of color, and except one expert disagreed and he suggests to use the light color or different use of color for each menu of button. Meanwhile for the last question (Q4) all of the experts agreed with the applied graphics and image but they comment to do not stretch graphics in page Info Tambahan. Figure 10 illustrates the results for user interface questions analysis.

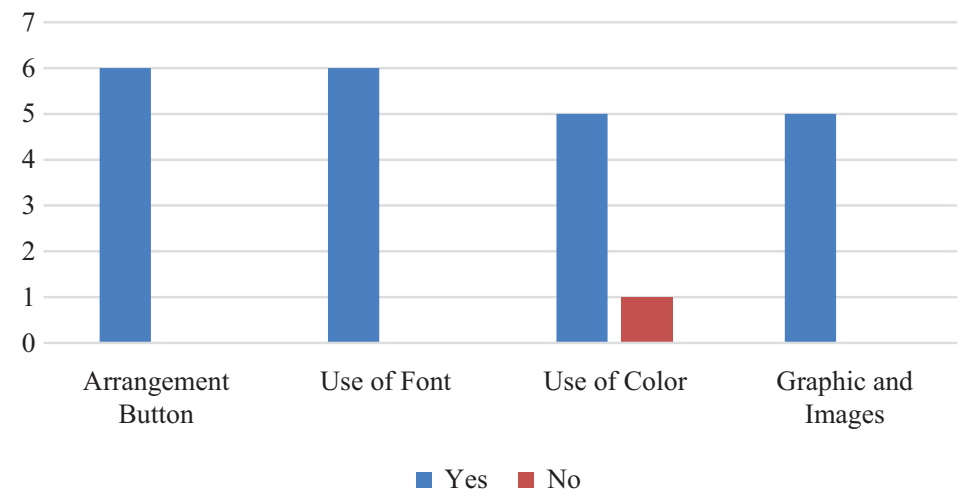

Fig. 10. User interface question analysis 


\subsection{Ease of use}

Table 4 listed the questions in terms ease of use of iZakat Kedah mobile application. Ease of use questions analysis and User usefulness questions analysis mentioned in Figure 11 \& Figure 12 respectively.

Table 4. Questions on ease of use

\begin{tabular}{|l|l|}
\hline \multicolumn{1}{|c|}{ No. } & \multicolumn{1}{c|}{ Questions } \\
\hline Q1 & Does all the provided buttons are functionable? \\
\hline Q2 & Does the video are well-function? \\
\hline Q3 & Does the calculator functionable? \\
\hline Q4 & Does the calculation of zakat provide accurate result? \\
\hline
\end{tabular}

Based on the interview is was found that all of the experts were $100 \%$ agreed with all the questions asked in terms of ease of use of iZakat Kedah mobile application.

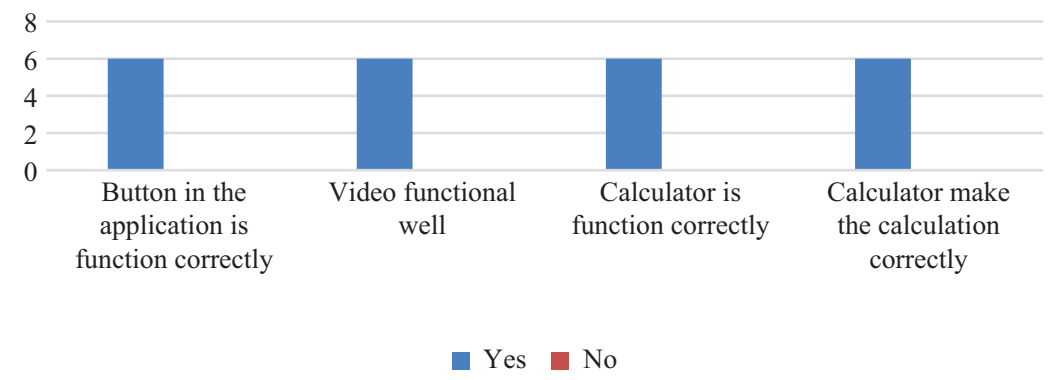

Fig. 11. Ease of use questions analysis

\subsection{User usefulness}

Table 5 listed the questions in terms of user usefulness of iZakat Kedah mobile application.

Table 5. Questions in terms of user usefulness

\begin{tabular}{|l|l|}
\hline \multicolumn{1}{|c|}{ No. } & \multicolumn{1}{c|}{ Questions } \\
\hline Q1 & Do the provided contents provide sufficient knowledge to the users? \\
\hline Q2 & Do the talks provides sufficient awareness to the users? \\
\hline Q3 & Does the video in Berita Zakat page provides useful news and information to the users? \\
\hline Q4 & $\begin{array}{l}\text { Does the provided video provide sufficient information regarding the distribution of zakat } \\
\text { income? }\end{array}$ \\
\hline Q5 & $\begin{array}{l}\text { Does the direction provided in page Lokasi Zakat could assists users to find the direction and } \\
\text { location to Zakat Branch Office? }\end{array}$ \\
\hline Q6 & Does the proposed calculator successfully expose the user to zakat income calculation? \\
\hline Q7 & Does the calculator make user feel easy to calculate their zakat income? \\
\hline
\end{tabular}


In terms of user usefulness, there are seven questions have been interviewed to the experts. It was found that upon utilizes the proposed application, all of the experts agreed with the usefulness of contents, talks, video, news, direction, and calculator provides in the iZakat Kedah mobile application.

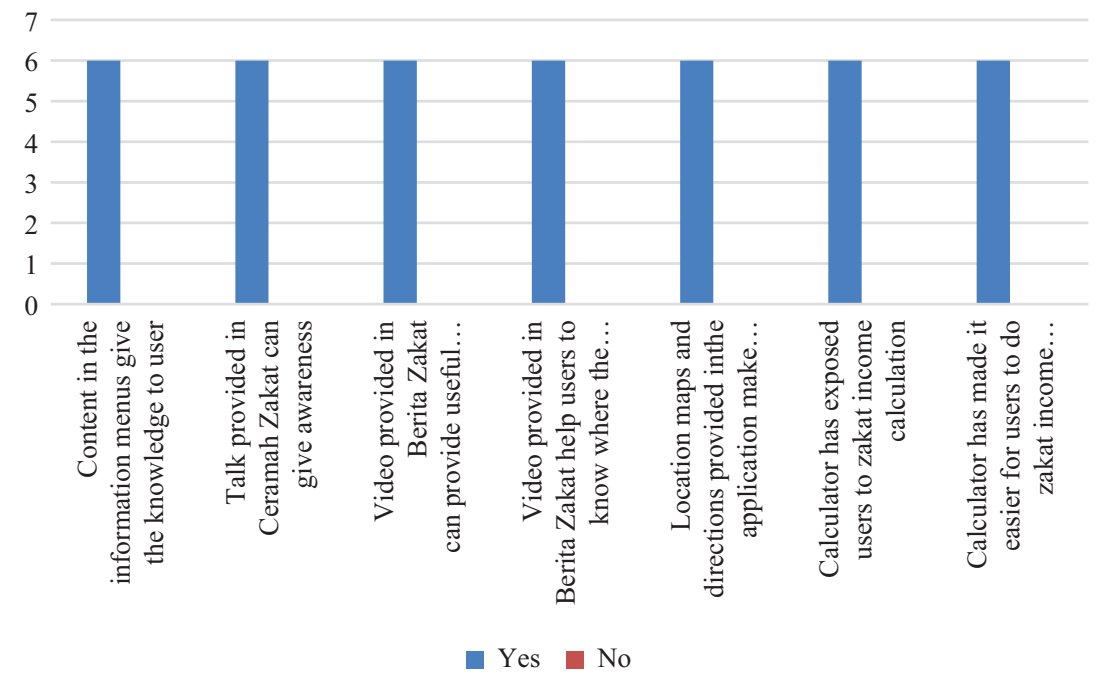

Fig. 12. User usefulness questions analysis

\subsection{Experts' comments}

Having conducted the face-to-face interview, this study then invites the experts to provide written and verbal comments to improve the proposed application particularly to fulfil the user needs. The written and verbals comments have been rearranged and presents in Table 6 .

Table 6. Experts' comments

\begin{tabular}{|c|c|}
\hline Experts & Comments \\
\hline Expert 1 & $\begin{array}{l}\text { - Use light color. } \\
\text { - Provide link that directly to YouTube for talk. } \\
\text { - Caption pop-up info in the calculator. } \\
\text { - Information is simple and more compact in zakat information. } \\
\text { - Add information regarding button for Kaedah A and Kaedah B. }\end{array}$ \\
\hline Expert 2 & $\begin{array}{l}\text { - Standardize the size of button. } \\
\text { - Use similar font size. } \\
\text { - Use bright color to attract the users. } \\
\text { - Use different color for menu button. } \\
\text { - Do not stretch the graphics and images. } \\
\text { - Add information regarding button for Kaedah A and Kaedah B. }\end{array}$ \\
\hline
\end{tabular}

(Continued) 
Table 6. Experts' comments (continued)

\begin{tabular}{|c|c|}
\hline Experts & Comments \\
\hline Expert 3 & $\begin{array}{l}\text { - A few videos need to be removed. } \\
\text { - Provides less heavy information. } \\
\text { - Avoids complicated information. } \\
\text { - Change the color of icon. } \\
\text { - Use recognize logo of application. }\end{array}$ \\
\hline Expert 4 & $\begin{array}{l}\text { - The menu button is too prominent. } \\
\text { - Use the light color for button. } \\
\text { - Provides instruction of calculation method. } \\
\text { - Add caption for direction. }\end{array}$ \\
\hline Expert 5 & $\begin{array}{l}\text { - Add additional information of zakat and distribution of zakat. } \\
\text { - Menu page should be in one page and no need to scroll. } \\
\text { - Menu button in one page. }\end{array}$ \\
\hline Expert 6 & $\begin{array}{l}\text { - Icon button should be in different color. } \\
\text { - Button and font should use the same size. } \\
\text { - Provides back button to home page in calculator page. }\end{array}$ \\
\hline
\end{tabular}

\subsection{Evaluated iZakat Kedah mobile application}

Having going through all the responses and comments from the experts this study decided to amend the iZakat Kedah mobile application based on expert's comments and recommendations. Therefore, the menu button in menu page has been redesign. Information for method of calculation has been added to button Kaedah $A$ and Kaedah B. Remove a few videos as suggested by the experts as well as redesign a minor part related to user interface. Figure 13 depicted some samples of interface design of iZakat Kedah mobile application that has been amended.
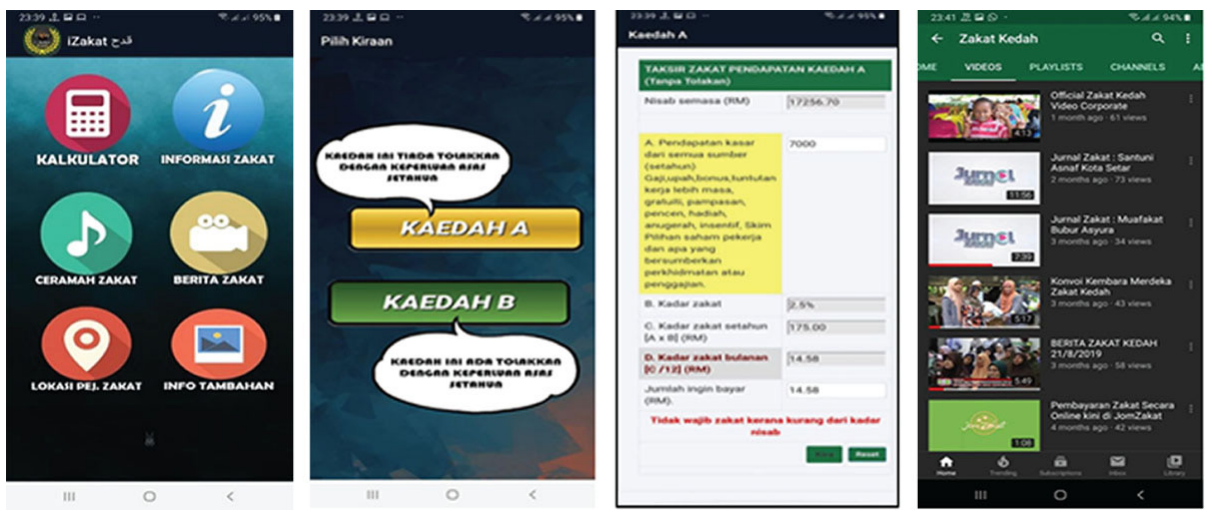

Fig. 13. User Interface amendments based on expert review suggestions 


\section{Conclusion}

To sum up, this study has achieved the main objective which is to proposed the iZakat Kedah mobile application to the public particularly for Muslims. A comprehensive comparative analysis including matrix analysis table has been carried out to extract the main components of iZakat Kedah mobile application. ADDIE Model has been adopted phase by phase to develop the iZakat Kedah mobile application. Having completed the development part, the proposed application then sends to evaluation stage. Expert review method has been conducted to review the iZakat Kedah mobile application. A series of closed-ended questions has been asked in terms of user interface, ease of use, and user usefulness. Results indicates that most of the experts agreed with the proposed design. However, there are some comments and suggestions from the experts to improve the design quality. Having analyse, all the comments and suggestions were taken into account. The iZakat Kedah mobile application was amend according to the expert's comments and suggestions. Future works of the study is to conduct the user experience testing of iZakat Kedah mobile application to the actual users.

\section{$7 \quad$ Acknowledgements}

The special recognition goes to the Center of Research and Innovation Management (RMIC), Universiti Utara Malaysia for the funding provided to this study through the University Grant Scheme. In addition, thank you to the FRGS-RACER grant scheme provided by Ministry of Education, Malaysia for the technical support (SO Code 14434). Also, to our research assistant Muhammad Nurasyraf Mohd Shahar Affendi and Inas Nurshazdweeni Ibrahim for their contribution in designing and developing the iZakat Kedah mobile application as well as special thank you to all the experts who provides the valuable comments to this study.

\section{References}

[1] Ghazali, M. Z., Saad, R., Jaffri \& Wahab, N. S. A. (2016). Proposing factors influencing trust towards zakat institutions amongst moslem business owners. In The European Proceedings of Social \& Behavioural Sciences - II International Scientific Symposium on Lifelong Wellbeing in the World (WELLSO), Russia. Retrieved from: https://www.researchgate.net/ publication/306387421_Proposing_Factors_Influencing_Trust towards_Zakat_Institutions_amongst_Moslem_Business_Owners; https://doi.org/10.15405/epsbs.2016.08.92

[2] Hairunnizam W., Sanep, A., \& Mohd ali mohd noor. (2007). kesedaran membayar zakat pendapatan di malaysia. Islamiyyat.

[3] Muhammad, F., Yahya, M., Hussin, M., Awang, S. A., Majid, A., \& Mohamed, T. (2016). Islam di Malaysia: Tertunaikah bayaran Zakat pendapatan? Islam in Malaysia: Would income Zakat be paid at all ? GEOGRAFIA OnlineTM Malaysian Journal of Society and Space 12 Issue 8 (48 - 60) (C) 2016, ISSN 2180-2491 48, 8(8), 48-60.

[4] Muhammad, F., Hussin, M., Awang, S., \& Mohamed, A. (2019). Islam di Malaysia: Tertunaikah bayaran Zakat pendapatan?. [online] Ejournal.ukm.my. Available at: http://ejournal.ukm.my/gmjss/article/view/17700/5444 [Accessed 28 Nov. 2019]. 
[5] Mohd Adib Abd Muin, Mohd Sollehudin Shuib. Azizah Che Omar, Amirul Haqeem Abd Ghani, Ruhaida Saidon \& Herman Shah Anuar. (2019). Kesan kadar haddul kifayah baharu dalam zakat pendapatan di negeri Kedah: Satu Pengenalan. International Journal of Zakat and Islamic Philanthropy, 1(2), 94-102.

[6] Razali Md Jani \& Muhsin Nor Paizin. (2017). Zakat Pendapatan Konsep Hawaij Asliyyah Mendasari Perbelanjaan Isi Rumah. Kuala Lumpur: Pusat Pungutan Zakat (PPZ).

[7] Zainal, H., Bakar, A. A., \& Saad, R. A. J. (2016). Reputation, satisfaction of zakat distribution, and service quality as determinant of stakeholder trust in zakat institutions. International Journal of Economics and Financial Issues, 6(75), 72-76. Retrieved from: https://www.econjournals.com/index.php/ijefi/article/view/3581; https://doi.org/10.15405/ epsbs.2016.08.74

[8] Murtaja A. S., Azham, B. H., \& Osamah M. J (2020). Usability Evaluation of Mobile Tracking Applications: A Systematic Review. International Journal of Interactive Mobile Technologies, 14(5), 119-128. https://doi.org/10.3991/ijim.v14i05.13353

\section{Authors}

Dr. Azizah Che Omar is a Senior Lecturer at School of Multimedia Technology and Communication (SMMTC), College of Arts and Science, Universiti Utara Malaysia (UUM). She is actively involved in research and publication, both internationally and nationally. Her research interests are in Design Research, Multimedia Learning, Media, Interaction Design, Affective Computing, Assistive Technology and Interactive Advertising. She has published more than 18 journals and 20 proceedings.

Ts. Dr. Nurulnadwan Aziz a Senior Lecturer at Universiti Teknologi MARA Cawangan Terengganu. Currently she has been appointed as Coordinator of Research Management Unit. Her research area is Multimedia Computing and experts in Human Computer Interaction, Augmented Reality, and Assistive Technology. She also has experience as Guest Editor for high impact journals (SCOPUS and WoS). Most of her research articles has been published by the prestigious publishers such as Springer and IEEE. She has won several research grants such as FRGS and RCF. She also is an active member of IEEE Computer Society and Malaysian Board of Technologies (MBOT).

Dr. Mohd Adib Abd Muin is a Senior Lecturer at Islamic Business School (IBS), College of Business, Universiti Utara Malaysia (UUM). Before joining UUM, he worked as an Assistant Manager at Bank Islam (M) Bhd under Automobile Financing Department. He also involved in the research related to Muamalat, Islamic Social Entrepreneurship and Islamic Finance and Banking.

Dr. Subashini Annamalai is a senior lecturer at the School of Multimedia Technology and Communication, Universiti Utara Malaysia. She has hybrid experience in information technology and multimedia and has been in the education field for more than 15 years. She has published articles in many Scopus journals in the area of her expertise. Her research interest includes (but not limited to) instructional multimedia, game development and human computer interaction.

Dr. Muhamad Amar Mahmad is a senior lecturer at the School of Language, Civilization and Philosophy, Universiti Utara Malaysia. Obtained a bachelor's, master's and doctoral degree in the field of da'wah and leadership at Universiti Kebangsaan Malaysia. Expertise is in the field of contemporary da'wah and Islamic leadership. 
He has published a few articles in the form of proceedings and journals related to da'wah and leadership. Currently, he is supervising several masters students of Islamic studies by research.

Article submitted 2021-04-29. Resubmitted 2021-07-01. Final acceptance 2021-07-02. Final version published as submitted by the authors. 